\section{c) 第了群}

以上の如き教㝋を 更に発展させ，片側 正常にして患側に急 性耳管炎及び急性耳 管中耳カタルを発病 と洪に有し，且つ， 多少とも著明な急性 鼻咽腔炎を有した。 急性㢣性㿡聴者 6 耳 （患側気尊損失 $80 \mathrm{db}$ 以上）に消炎療法及 び鼻咽坨治療を斿行患側の耳管炎の治瘾に伴 い, 聴力子全く正常に迄（年路的変化子教虑）

6 耳とも恢聁し，1.2. 橉に於て観察された結果 が必ずしも間違いでないことを確信した。表6.

7.は，その中の 2 例の初診時及び治療した洔期 の Audiogram である。

\section{4. 結 論}

原因不明の内耳性障碍の中，耳管炎を合併す
第 7 表

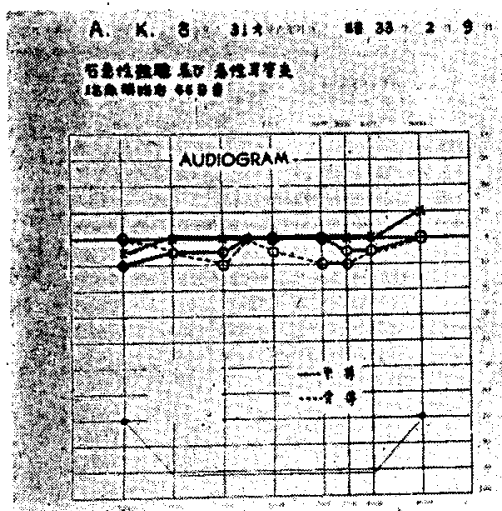

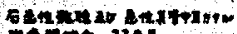
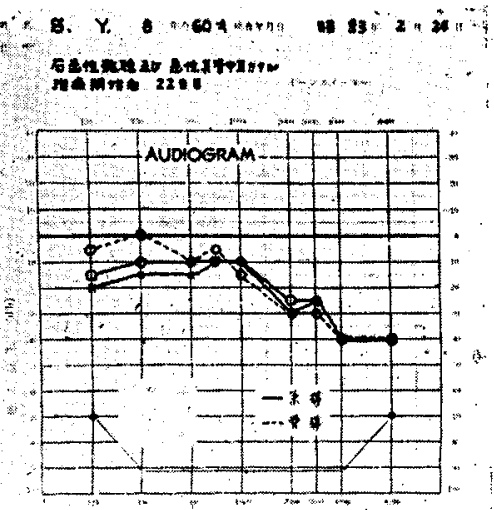

るもの多く，又耳管炎患者の Audiogram を 連続的に観察して行くと, 内耳性障碍の $\mathrm{Au}$ diogram に迄到達することが屡々ある。この 点から吾及は本研究に着手した由であり, 今後 共本䦓題の梌索により一層の努力をしたいと考 えているものではあるが，今回は，特に耳管炎 は可成りに内耳障碍を惹起する可能性を充分に 有することを強調した。

高齡者の聴力についての再検

\section{1. 粕言}

高年跉になるにしたがい，聴力が低下するこ とはよく知られたことであるが，その低下の程 度は各個人により珙なり，その低下の型む漸傾 型，急整型と区別されている。しかし振り返つ て現在までの研究を眺めてみると，いゔれも来 院患者, 慇老院入所を対象としているために, これをもつて一般老人の聴力を云々することは 出来ない。

私達のこの調查の対象は，比較的都市農村の 複合構成地区である横浜市戸塚区在住の60歳以 上の高路者より，無作為抽出法により選び出し た一般生活者である。

此の調查は, 東大公衆衛生教室, 戸塚保健所 等と共同で行われ，各科諸検查が合せ行われ

設 楽 哲也沢木修二
藤 田茰朗(東大)

た。

\section{3. 実験 対 象}

横浜市戸塚地区在住の60㵴以上の高柃者総数 5028 名より，船作為抽出法により選出した 377 名に，前もつて用意した既往歴，主訴について の質開用紙を渡して記入せしめ，次いで耳鼻科 的一般検查を行なつた。

377名中, 䟡音を受けたとの 既往歴がなく鼓 膜所見のないものを選出し，オーデオメーター により間柭椧查を行なつた。

オーヂオメーターは小林理研 06 型を伐用 し，小林理研の移動用防音㗍内で測定した。

気尊測定は必らず右側耳より行ない，1,000 cps. 2,000 cps. 4,000 cps. 8,000 cps. 500 cps. $250 \mathrm{cps}$ の 6 点を上界法により測定した。 
右耳で充分に練翼して測定に被験者が馴れてか ら左耳を測定した。この際，ォーヂォメーター 附属のシグナルは使用せず指の上下で合図せし めた。測定結果は，左耳のみを採用し，右耳測 定値は使用しなかつた。次に骨遒閾值を測定 し， $1,000 \mathrm{cps}$ で気導骨導值差 $10 \mathrm{db}$ 以上のも のは取除いた。此の結果, 測定値採用耳は 146

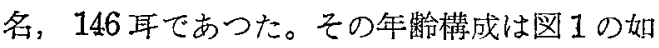
くである。

\begin{tabular}{|c|c|c|c|c|}
\hline \multicolumn{6}{|c|}{ 図 } \\
\hline 年 齡 & $61 \sim 65$ & $66 \sim 70$ & $71 \sim$ & 計 \\
\hline 男 & 40 & 30 & 14 & 84 \\
女 & 25 & 21 & 16 & 62 \\
計 & 65 & 51 & 30 & 146 \\
\hline
\end{tabular}

更にこのうち 105 名に明膫度検查を行なつ た。その年䤅構成は（図 2 ）の如くである。

\begin{tabular}{|c|c|c|c|c|}
\hline \multicolumn{5}{|c|}{ 図 } \\
\hline 年齢 & $61 \sim 65$ & $66 \sim 70$ & $71 \sim$ & 計 \\
\hline & 30 & 18 & 16 & 64 \\
女 & 18 & 13 & 10 & 41 \\
女 & 48 & 31 & 26 & .105 \\
\hline
\end{tabular}

図 3

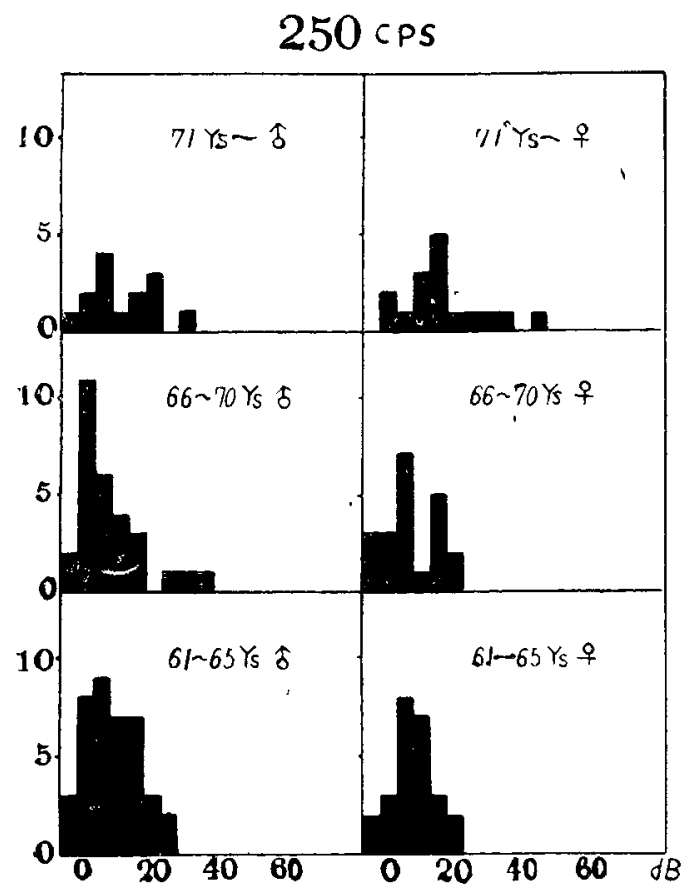

測定日数は，32年 9 月より10月にわたり，計 3 週間を要した。

\section{3. 測定成績}

a. 各周波数の年路剻, 性別比較（図 3 8) $250 \mathrm{cps}, 500 \mathrm{cps}$ の低音域では, 男女差は殆 んどなく，各年䛧㖤のばらつきは狭い。又，年 囹により聴力低下が見られるが著明ではない。

$1,000 \mathrm{cps}, 2,000 \mathrm{cps}$ の中音域では，低音域 と較べ，各年鲙層のばらつきは执くなり，德力 低下者が増加する。男女差は殆んど見られな い。年柃の移動による聴力低下程度は低音域よ り著明である。

\section{4,000 cps になると，各年歯畨のばらつきは} 一層悪い方に桩がり，且，年略による移動も湛 だしい。男女を比較すると，男性では各年龄層 とも女性よりも悪い方（図では右）にばらつき が拡がつている。そのばらつき状態を検討する と，女性では，二つのばらつき群即ち，20dbを 頂点とする群と, $35 \mathrm{db}$ 附近を頂点とする群と に分かれ，この二つの群は，年盽とともにそろ つて右方にずれる。しかるに男性では，このよ

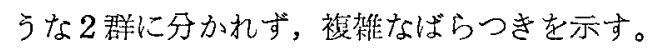

\section{図 4}

500 CPS

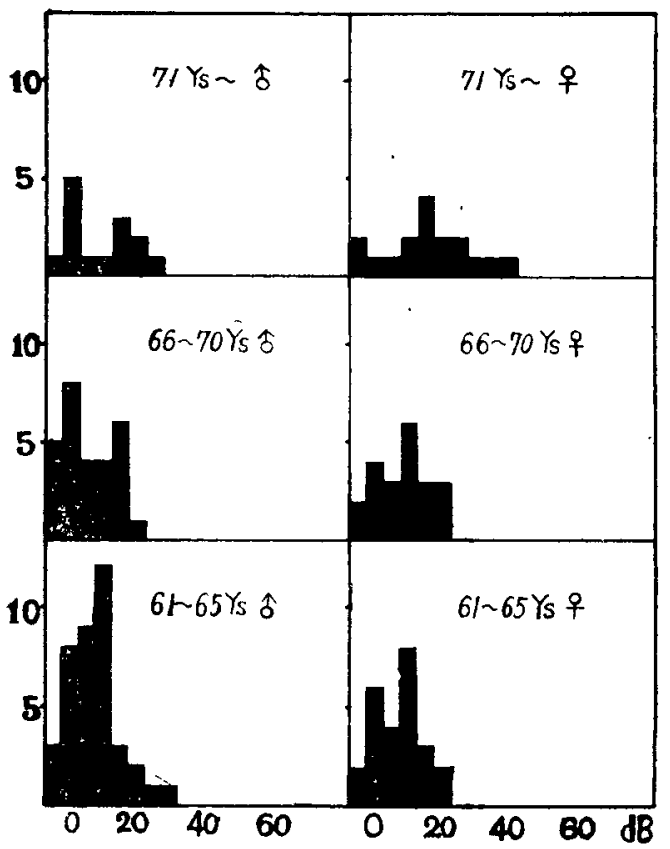


図 5

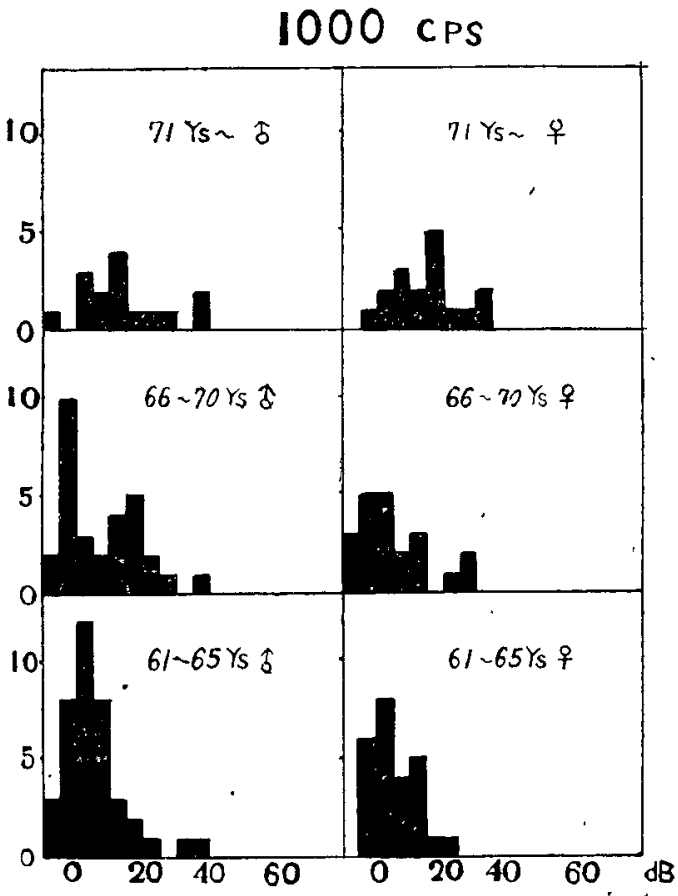

$8,000 \mathrm{cps}$ では，再び男女养ははつきりしな

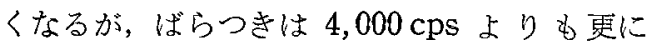
拡がる。

b. 聴力型の性差年睔美

以上，各問波数のばらつきを示したが，更に 聴力型（從来，急墜型，漸傾型と区別された） との関係を求める目的で $1,000 \mathrm{cps} .4,000 \mathrm{cps}$ とを同時に示す図を作つた（図9.10)。

図で右上部に害かれた点は急墜型を示し中央 斜線に近い点は漸傾型と呼ばれたものを示す。

女性では， $4,000 \mathrm{cps} に 2$ 群見られることを すでに述べたが，その 2 群を（図 9 ）で求める と，61〜65歳では実線に囲まれた部位を示す。 この 2 群は年业命と共に矢印の方向に進むように 見光る。

男性では，(図 7 ）では二つの群が認められ なかつたが，（図10）では姓と同様に 2 群存 在することが判る，ただ 2 群とも右手に大きく すそを引く(点線で国まれた部位)。

c. $4,000 \mathrm{cps} .8,000 \mathrm{cps}$ との関係,

$4,000 \mathrm{cps}$ 測定值のばらつきが，男性では女 性よりも䂃広く，且つ聴力低下者が多いこどを 述べたが， $8,000 \mathrm{cps}$ と $4,000 \mathrm{cps}$ 測定値との
图 6

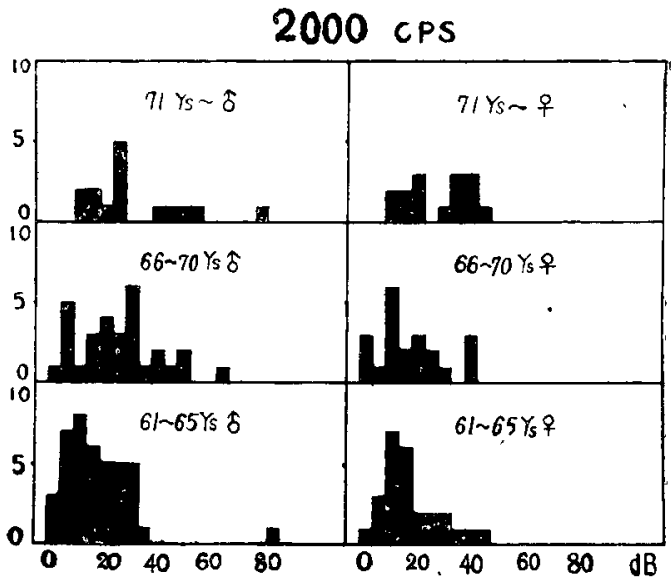

图 7

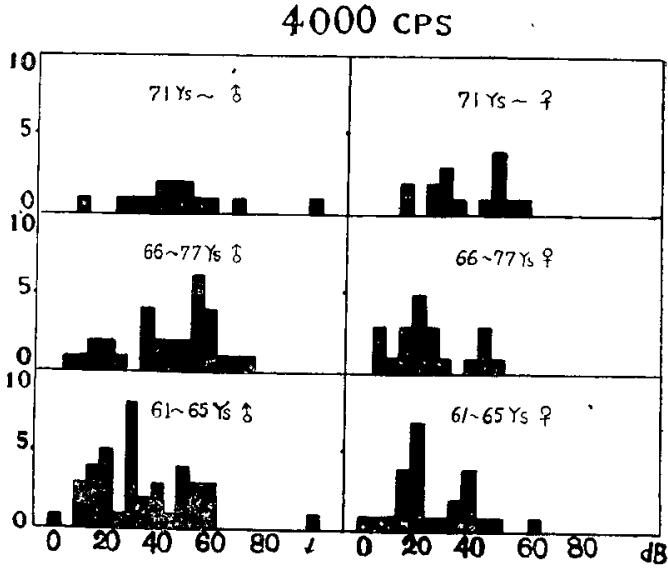

図 8

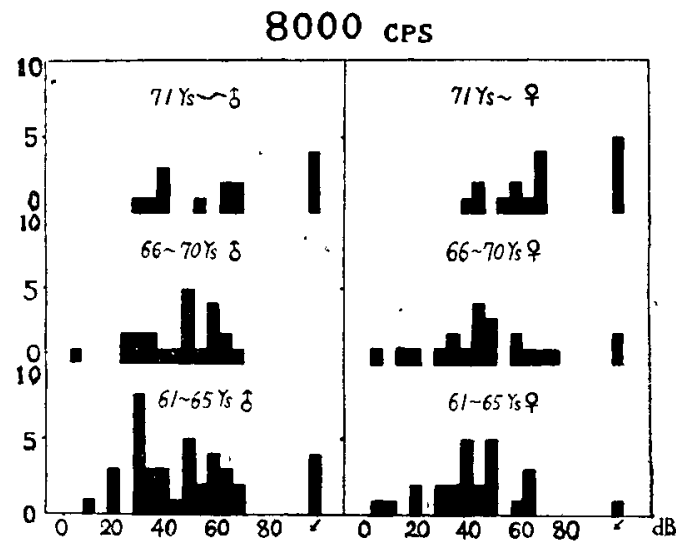

関係図（図11）を作り，男女差を検討した。男 性では女焅よりも，8,000 cps では同じ值を示 

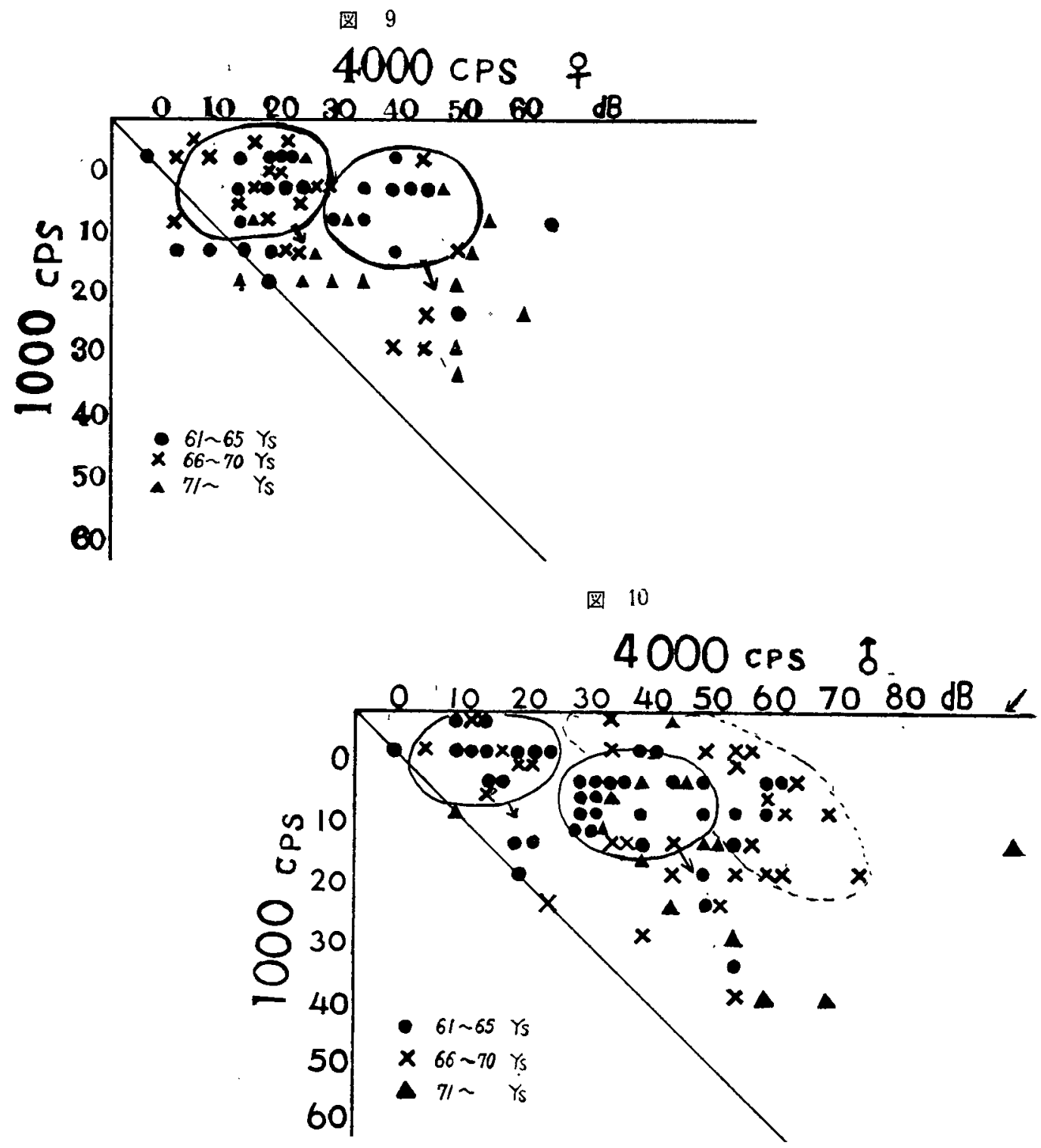

すにかかわらず， 4,000 cps の低下したものが 多い事が判る。

d. 聴力と, 血圧, 眼底動脈硬化度, 血中二 レステロール等との関係。

Scheie の分類に従い眼底動脈硬化度を分類 し，それと聴力との関係を求めた（図12.13） 全く関係が認められない。

同様に, 最高血压, 最低血压, Scheie の血 圧分類, 血中コレステロール等との関係を求め
たが，いつれも相関関係は認められなかつた。 4.〜老人性難聴の分類

1）聴力型より $\left\{\begin{array}{l}\text { 生理的老人性獏聴 } \\ \text { 本態性老人性難聴 } \\ \text { 環境性老人性難聴 }\end{array}\right.$

2）臨床的に $\left\{\begin{array}{l}\text { 生理的老人性難聴 } \\ \text { 病的老人性嚾聴 }\end{array}\right.$

この臨床的分類は, 年㢼平均值に考慮せず， 明瞭度の調査（図17〜18）により明膫度の悪化 
程度を考慮して約束した。

\section{5. 結語}

高踰者の聴力の男女差を検討すると， 4,0 $00 \mathrm{cps}$ では，男性には女性よりも聴力低下者 が多い。この低下の原因は無意識の虽音と考

\section{える。}

聴力の低下状態を観察すると二つの群に分 かれる。これは従来の急墜型, 漸傾型の分類 とは哄なる。

聴力の低下程度と, 血圧, 眼底動脈硬化, 血中コレステロールとの間に相関関係はな w。

老人の聴力を聴力型より 3 群に, 臨床的に 2 群に分類した。

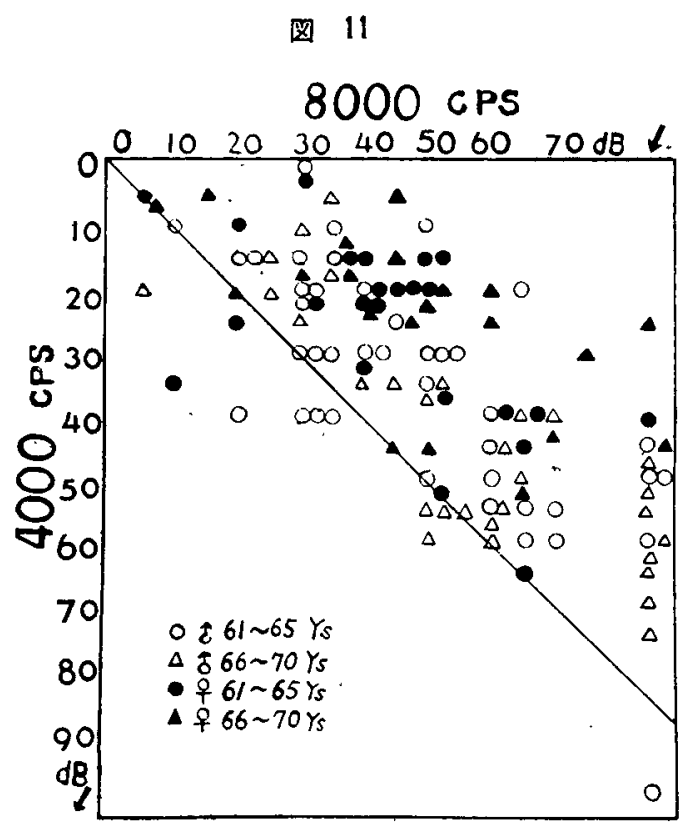

图 12

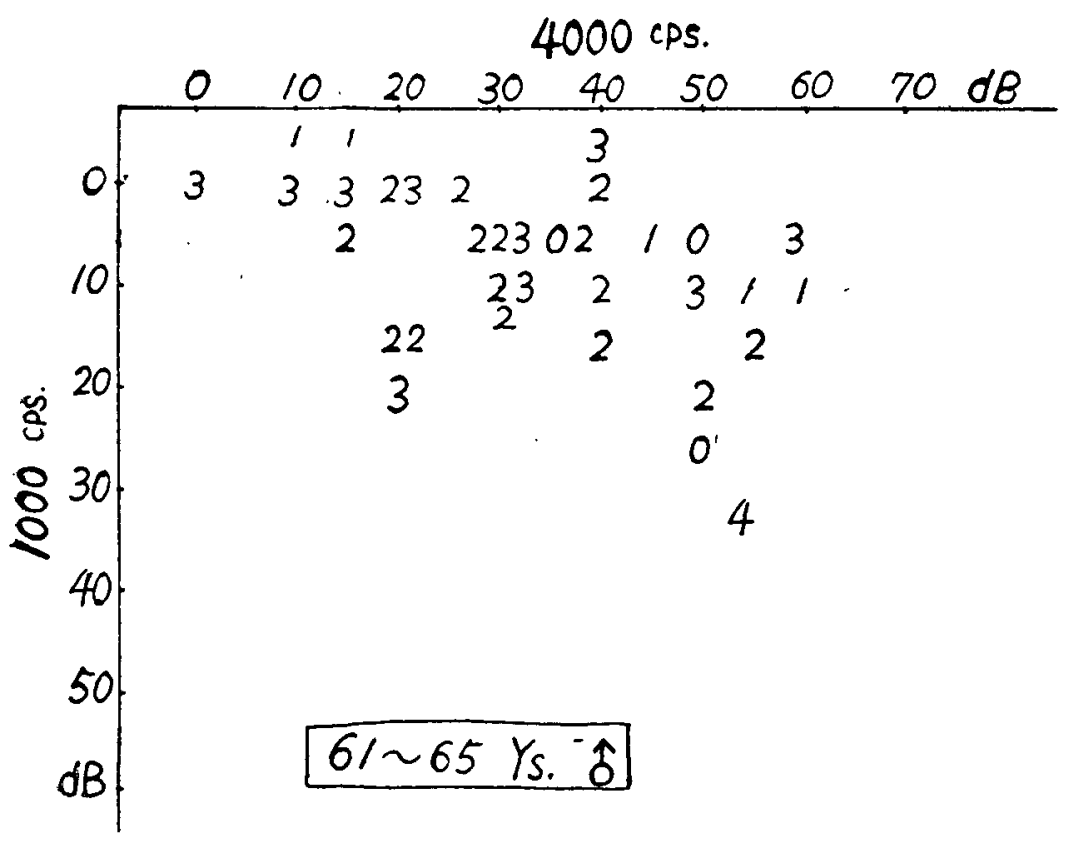




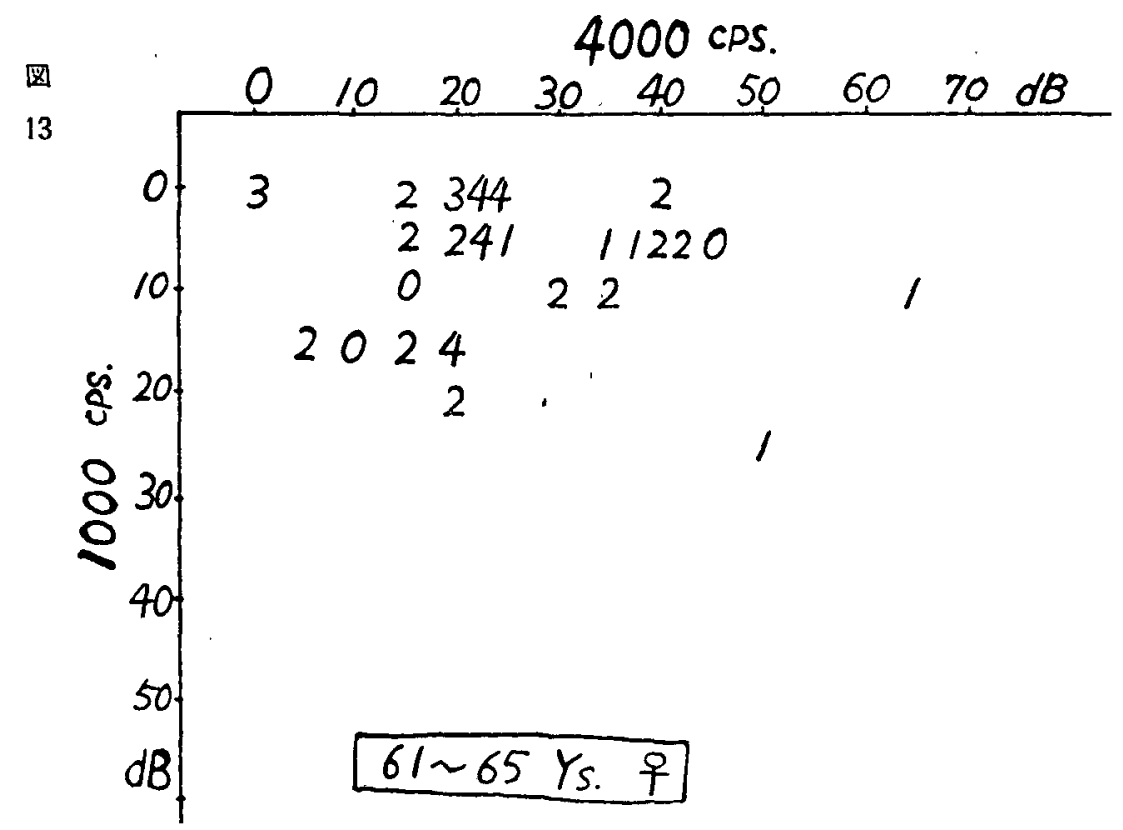

図 14 単純平均による61〜 70歳の聴カ

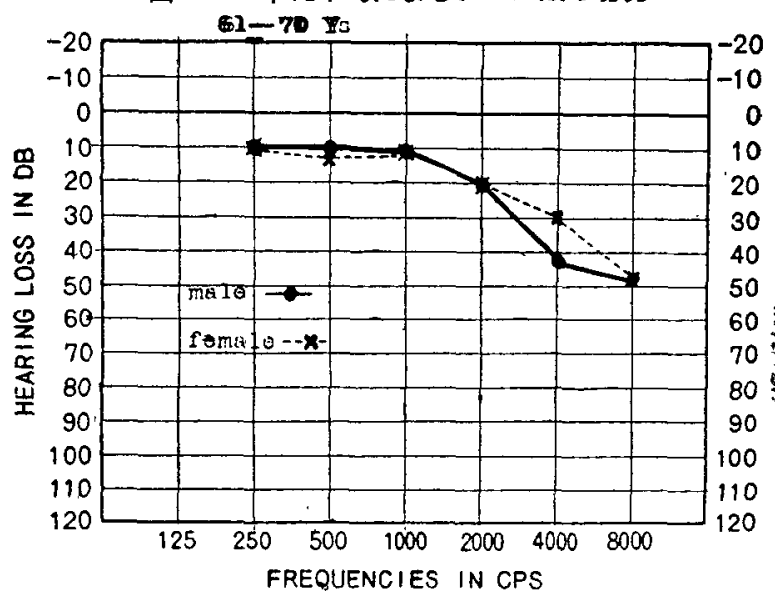

図 15 聴力 型

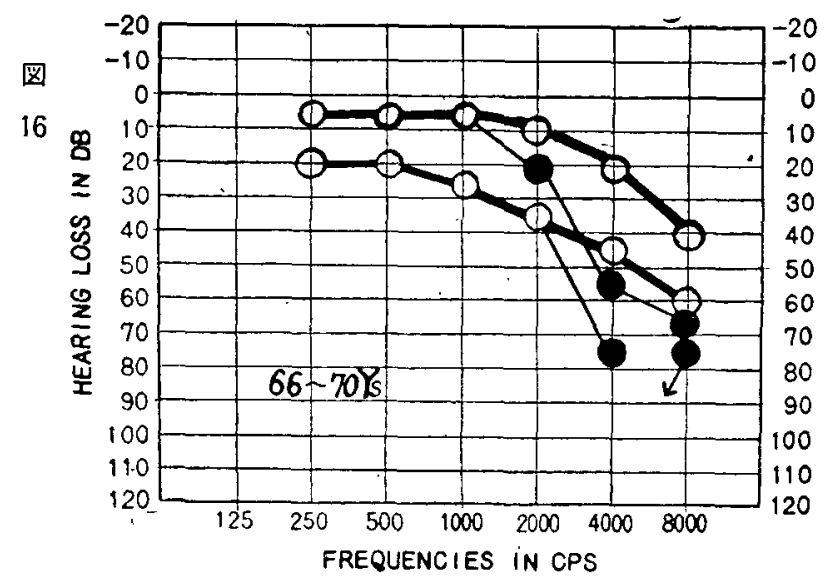


図 17

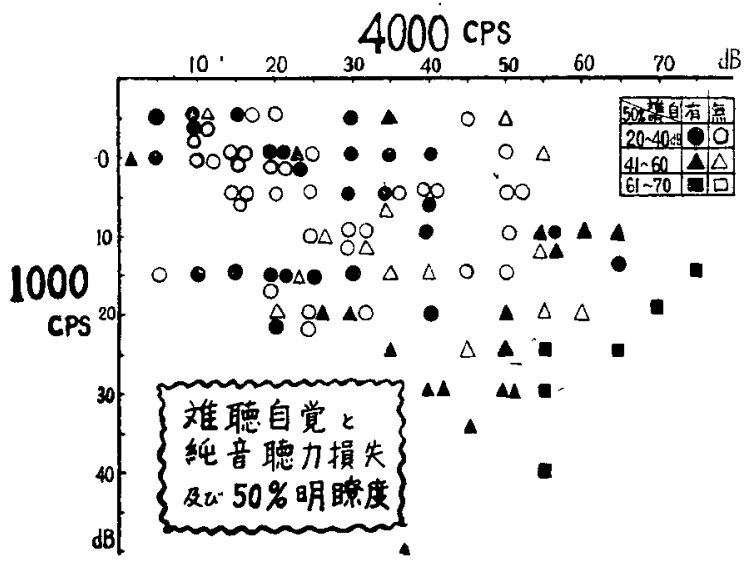

図 18

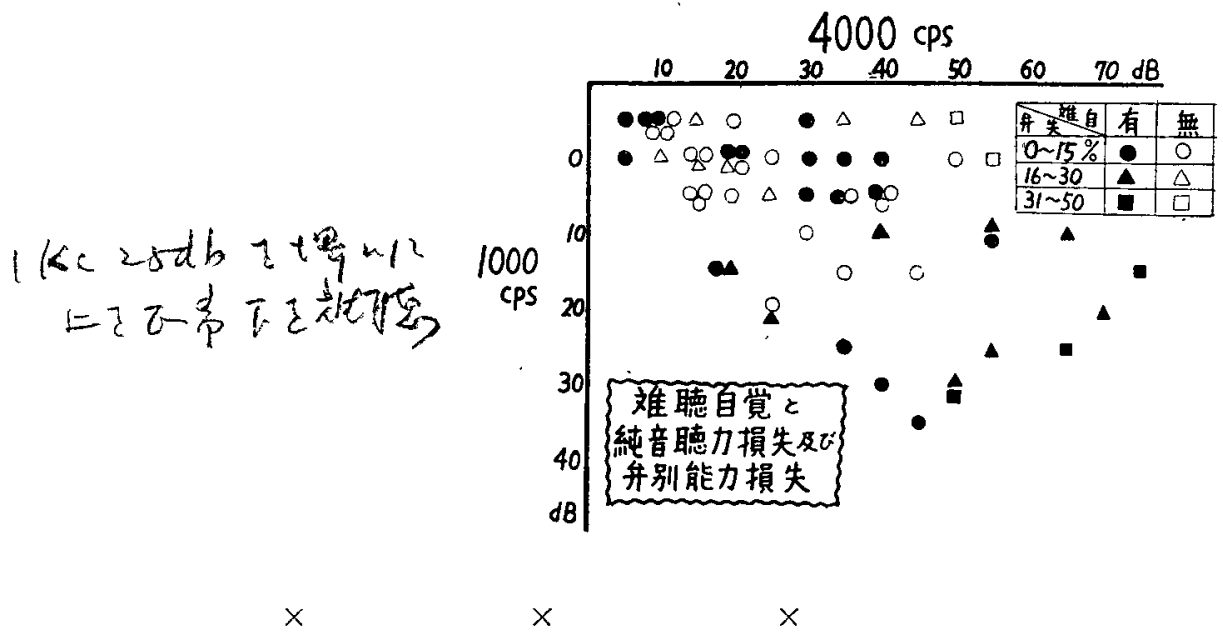

SM 難聴予防の臨床的観察

$$
\begin{aligned}
& \text { 久保正雄沢田信敏 } \\
& \text { 志多亭森幸紀(大阪鉄道) }
\end{aligned}
$$

$\mathrm{SM}$ 難聴予防の目的にチョコラA，アリナミ ン, コンドロイチン硫酸の静注を每SM注射每 に行い, 約 1 年間に亘り逐次気導聴力を測定し てその效果を無処置群と比較検討した。1 群約 50名宛の成績である。
〔備考〕本観察の中間報告は去る6月の近畿耳 䙹咽喉科学会で報告したのでそのデータはある が，その後の成績を加えたものは当日会場でプ リント配布する積りである。 